\title{
ACCOUNTING FOR THE COSTS AND BENEFITS OF HUMAN RESOURCE DEVELOPMENT PROGRAMS: AN INTERDISCIPLINARY APPROACH*
}

\author{
PHILIP H. MIRVIS and BARRY A. MACY \\ University of Michigan
}

\begin{abstract}
An interdisciplinary approach to measuring the costs and social and financial benefits of human resource development is presented. The approach includes three distinct components: a cost model, an effectiveness model, and a cost-benefit comparison. The diverse interdisciplinary measures of development programs are presented. A critical discussion of the role of human resource accounting and other accounting measures in evaluation is included. Examples from two organizations illustrate the measurement approach. An examination of program evaluation criteria highlights the effect of cost -benefit analyses on the human resource development movement.
\end{abstract}

Even the casual reader of the organizational literature has noted that working people have come to be regarded as human resources. This transition is not simply a shift in terminology or a rephrasing of traditional managerial values, rather a semantic reflection of the heightened awareness of employees' importance to the firm. Bakke (1961 : p. 24) captured this philosophy by characterizing the human resource function as a distinct series of managerial responsibilities and practices designed to

"achieve productive work and arrange for the maximum opportunity for expression of the full range of people's abilities and capacities in that productive work."

Most recently, Mills (1975) employs human resource development, HRD, as a acronym for a wide range of behavioral science and management technologies intended to improve both the operating effectiveness of the firm and the quality of working life experienced by its employees.

Behavioral scientists have been the most active in this movement, designing tools for stimulating and effecting organizational changes consistent with those aims. They have experimented with job enrichment, interpersonal training programs, participative management, and autonomous work groups in a variety of organizations (see reviews in Work in America, 1972; Davis \& Cherns, 1975). Yet, as two recent reviews of the field report, there is a paucity of well documented assessments of these projects (Katzell et al, 1975; Srivastva et al., 1975). Instead, there are a series of case studies, characterizing the experimental technologies and their implementation, but offering only a minimal evaluation of their effects.

Kahn (1974) and others have noted that, as a result, there is little comparative evidence by which to evaluate the strength and generalizability of these various technologies. Moreoever, practicing managers and decision makers, unguided by systematic evaluations of past experiments, remain uninformed as to the cost and benefits of various development programs when contemplating experimentation in their own organizations. Consequently, Ash (1973) and others have questioned the current enthusiasm for human resource development and quality of work.

*This paper was prepared in connection with research being conducted in the Quality of Work Program, Survey Research Center, Institute for Social Research, University of Michigan and supported by the Ford Foundation (Grant No. 740-0430) and the United States Development Administration (Grant No. 99-06-009377) and the National Commission on Productivity. 
Accounting techniques are presently being developed which will test the merits of HRD. Alexander (1971) has proposed cost-benefit analyses of these programs. Pyle (1970) suggests using human resource accounting to compute a return-on-investment in human resources. Cheek (1973) reports on cost-effectiveness evaluations of personnel programs. This paper will examine these techniques and the more general role of accounting in HRD research. Admittedly, accounting has a circumscribed role, for assessment of these projects has an interdisciplinary flavor, attracting the services of psychologists, sociologists, and engineers, too. Nevertheless, some distinct accounting contributions can be identified, and this paper will report on the successes and limitations of the first applications.

\section{A FRAMEWORK FOR HRD RESEARCH}

Human resource development efforts produce multiple effects: work settings may be altered, attitudes may be improved, behavior may be changed, and financial benefits may accrue. The research function is to measure and report these effects. Yet, Steele (1973) and others have criticized research limited to program evaluation. They argue for research designed to generate and validate theory and principles. As such, the researchers' responsibilities include not only identifying program effects, but tracing their causal lineage. Further, the researchers must assess the costs and gains of these programs to guide future HRD decision making. This requires:

1. An underlying theory of human resource development which specifies the social and financial effects of HRD;

2. Broad measurement of the development program and a research design suited for causal inference; and

3. A model of financial assessment for determining the costs and benefits of HRD.

\section{A theory of human resource development}

The HRD research effort should not be left to a particular researcher's whim or convenience. It must be guided by an underlying theory of program effectiveness and employee development. This enables the researcher to: (1) identify variables likely to be influenced by the HRD efforts, and (2) formulate and test hypotheses regarding the intervening processes that produce the effects. As such, assessment incorporates not only the outcomes, but the process of HRD.

HRD programs can concentrate on individuals and their work setting. Resources may be allocated to produce structural changes in the nature of employee's jobs, work assignments, supervision, and so on, creating a more challenging and stimulating work environment. These changes are sometimes coordinated with interpersonally oriented programs, designed to facilitate employee's integration into the new working environment. Both these activities are intended to alter employee's perceptions of their jobs and their experienced work environment. They manifest themselves through individual growth, selfdirection, satisfaction, physical and mental wellbeing. While this is a normative expectation, ignoring the quality and appropriateness of the development efforts and individual reactions to particular programs, it underscores the contention that HRD can effect socially-oriented objectives.

HRD can produce financial results, too. Employee's behavior may be conceptualized as a decision making process. Employees make choices about being available to work (March \& Simon, 1958 ) and choices about how to perform at work (Lawler, 1973). Research indicates that employees will be more likely to come to work, rather than be absent or quit, if they obtain satisfaction from their jobs (Porter \& Steers, 1973). They are likely to give more effort and better utilize new working methods if they expect to be rewarded for their efforts (Vroom, 1964). Thus, as HRD programs alter working environments and influence employee's perceptions of their jobs and their satisfaction, they should also effect employee's decisions with respect to job-related behavior. Resulting changes in absenteeism, turnover, accidents, and performance, in tum, will effect the operating effectiveness of the firm. Again, this is a normative view, but illustrates how IIRD can impact financial objectives.

The purpose of HRD assessment is to measure the accomplishment of these social and financial aims. By incorporating and validating the underlying theory, however, researchers can come to document how these effects are produced and under what conditions. Toward this end, longitudinal assessment must be undertaken within the context of a research design and expansive measurement approach. 


\section{$H R D$ research design and measurement}

To document that changes in intervening processes and outcomes are due to HRD activities, behavioral scientists have begun utilizing quasiexperimental designs in the field. Frequently, they employ comparison groups to assess the relative effects of the projects (see discussion by Sherwood, Morris \& Sherwood, 1975). In practice, however, a myriad of exogenous events often cloud parallels between experimental and comparison groups and it becomes difficult to trace changes in employee's attitudes and behavior to particular development activities (see discussion by Weiss \& Rein, 1970).

In response, Lawler (1975) calls for interdisciplinary assessment of these HRD projects over time. By evaluating these projects using measures from different disciplines, the researchers seek convergent validity between multiple measures of program effects (see discussion by Edwards, Guttentag \& Snapper, 1975). This argues for formation of an interdisciplinary research team to document both the process and outcomes of HRD. The immediate effects of the human resource development project can be captured via on-site observation. Sociologists can assess changes in the formal structures of the organization such as decision making and communication patterns. Engineers can evaluate improved work methods and estimate their effects on the costs of goods and services. Psychologists can document changes in employee's attitudes and behavior. The accountant's function, where possible, is to assess the project in financial terms.

\section{A model of financial assessment}

Ideally, the accountant can report the costs and benefits of these projects. Figure 1 presents a cost-benefit approach for assessing HRD projects. The figure depicts several different development programs, $x_{1}-x_{5}$. There are three distinct accounting activities (King, 1970) necessary for evaluating these programs: (1) a cost model needed for identifying the firm's direct costs and losses in productive time traced to the development effort; (2) an effectiveness model used for measuring and validating the effects of a project on the work environment and employees' attitudes, behaviors, and performance and expressing these effects in financial terms; and (3) a synthesizing model needed to compare the costs and benefits of a program. Both social and financial goals can be contrasted with project costs. The synthesizing model is used to identify either the most cost-effective or most costbeneficial HRD program. Both criteria can be used when evaluating a number of HRD efforts.

Armed with a theory of employee development, a broad array of measures, and a model of financial assessment, researchers are prepared to evaluate a HRD program. The remainder of this paper will consider the accounting tasks in this endeavor, noting the particular measurement methods and strategies and providing some illustrative examples.

\section{THE ACCOUNTING FUNCTIONS}

\section{Identifying the costs of an HRD program}

It would seem evident that organizations would want to know what they spend on human resource development. Yet, in many organizations their expenditures are scattered in the budgetary accounts of various cost centers. Following the introduction of human resource accounting dissaggregation guidelines (Brummet, Flamboltz \& Pyle, 1968), however, an organization's expenseper-employee can be computed.

Human resource accounting, as envisioned by Likert (1961), treats these expenditures as an

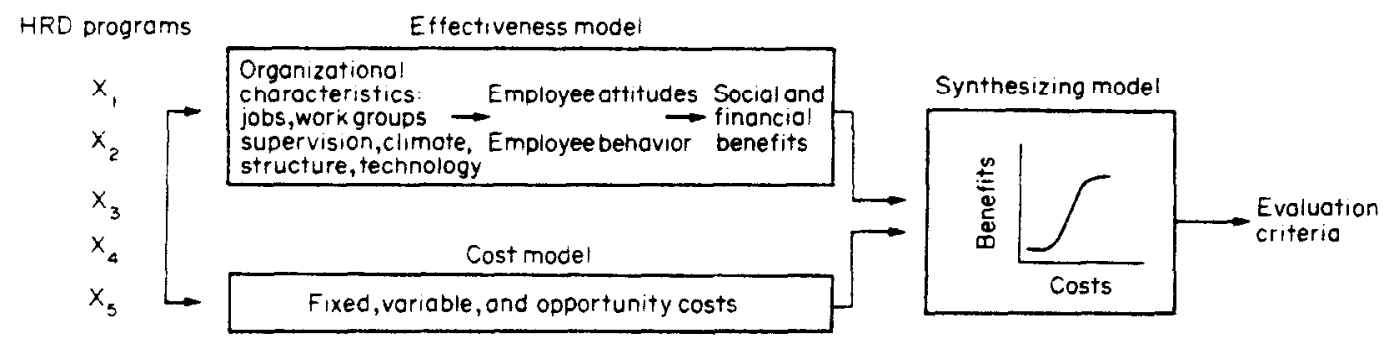

Fig. 1. Cost -benefit model for HRD programs. 
investment in employees, indicative of their value to the firm (Woodruff, 1970). The logic behind this is straightforward, arguing that development costs produce benefits beyond the current accounting period. However, a number of researchers have challenged the accuracy and utility of human asset valuation.

Specifically, Lawler (1974) and others have questioned the legal and ethical implications of human asset valuation. In rejoinder, Flamholtz (1974) contends that employees' services are the appropriate asset, and offers a stochastic model valuing predicted service time, a process analogous to valuation of capital investments. Mirvis \& Macy (1976) note the absence of convergence between different valuation models. Flamholtz (1972) argues instead for surrogate measures of value and reports finding convergent validity between measures of replacement costs, performance, and compensation and discriminant validity vs other valuation methods. Nevertheless, these surrogate measures are hardly inviolate, failing to contend with a non-interval salary structure and differences between wages and marginal productivity.

This is not to say that human resource accounting is not useful for HRD. Indeed, if employer's expenses in these projects can be capitalized, it may help to stimulate future expenditures. Rather, it is the assignment of value to individual's services that raises problems for HRD research. To evaluate a specific HRD program, the researcher must distinguish the investment value-per-employee. If gross or net book value is used, Rhode \& Lawler (1973) note there is no accounting for individual differences in skill acquisition and development. Beyond these individual differences, there is also the potential for group or situational variability. If economic value is used, there is a danger of circularity when comparing the investment with the financial return, for anticipated benefits are incorporated in the initial valuation (see discussion by Dearden, 1969). Given these troubling measurement issues, Macy \& Mirvis (1976) argue that for research and assessment purposes, these expenditures should be treated as costs. As such, they can be contrasted with future benefits using the cost-benefit calculus.

Notwithstanding these objections, many of the tools developed by human resource accountants can be utilized in assessing the costs of human resource development. Human resource accountants have distinguished the fixed, variable, and opportunity costs of HRD efforts. Variable costs include the consultants' fees and expenses associated with their activities. These costs vary depending on the type of program and the intensity and duration of the development activities, and should be reported in deflated dollar terms. The site incurs variable costs, too, in the form of lost worker productivity and overtime. The project's fixed costs include salaries, wages, and benefits associated with employees' lost time, and the resulting unabsorbed burden. Opportunity costs reflect the profit contribution of employees' lost time. In addition, there is an estimable opportunity cost, the "opportunities foregone" (Rothenberg, 1975) which might have been realized had the HRD resources been directed toward other organizational ends.

\section{Measuring the benefits of an HRD program}

As an HRD program takes effect, changes should be observed in the work environment. Consequently, attitudes and behaviors may be altered and, as HRD theory proposes, social and financial benefits should result. Recently, several accounting methods have been advanced to measure these benefits in monetary terms.

Financial benefits. Following an HRD program, major financial benefits could be realized in increased productivity and cost savings associated with reduced absenteeism and turnover. Herrick (1975), recognizing this possibility, proposed a group of nonproductive behaviors likely to be influenced by human resource development programs. He further suggested reporting the cost savings associated with reductions in these behaviors.

The expression of behavior in financial terms is not a novel idea. A classic article by Brogden \& Taylor (1950) addressed the potential for developing on-the-job performance criteria in cost accounting terms. Rather, it is the intention to systematically identify, define, measure, and financially quantify the behavioral and perfor. mance outcomes of employees that represents a new undertaking. This shifts the emphasis from assigning a value to employees, to assessing the economic consequences of their behavior.

Macy \& Mirvis (1976) developed the behavioral-economic methodology for defining, measuring, and costing the behaviors likely to be influenced by human resource development 
efforts. They provide three criteria for inclusion of a behavior:

1. It had to be defined so that it was significantly affected by the work structure;

2. It had to be measurable and convertible to significant costs to the organization;

3. The measures and costs of the behaviors had to be mutually exclusive.

Consistent with these criteria, behavioral definitions were devised, distinguishing behaviors such as absence because of jury duty, funerals, maternity, and so on from those related to the work environment. Behaviors like alcohol consumption were omitted, for though potentially related to working conditions, they manifest themselves in the costly behaviors of absenteeism and tardiness.

The research identified ten behavioral variables in two broad categories:

Participation-membership. Absenteeism Turnover - Strikes - Tardiness.

Performance-on-the-job. Production under standard - Quality under standard - Grievances Accidents - Unscheduled downtime and machine repair - Material utilization and inventory shrinkage.

Coupling behavioral definitions with standard measures developed from governmental reporting requirements and accepted organizational and accounting practices provided the behavioral indices from which to allocate the costs to a firm. The costs were conceptualized in two fashions. The first provided a distinction between outlay and time costs, the second between fixed, variable, and opportunity costs. These reflect direct and indirect costs and lost profit potential. An example of a variable cost would be paid overtime traced to absenteeism; a fixed cost would be salaries plus benefits of personnel involved in replacing the absent worker, while an opportunity cost would be the profit lost during the replacement process. These distinctions are important as only variable costs are directly related to incidents of nonproductive behavior. Fixed and opportunity costs will probably vary only with incremental changes in those incidence levels.

Using this methodology, a researcher can identify the financial outcomes of a human resource development project. Variable savings might include improved marginal productivity through increased product quality and quantity, limited overtime, reduced supply and material consumption, and less unscheduled maintenance. Further, wages and other expenses due to absenteeism, accidents, and grievances could be decreased. These would include the expense of maintaining a replacement work force. Potential fixed savings could be realized if some of the service demands placed on the personnel, industrial relations, safety, and quality control departments were reduced. Opportunity savings might be realized if supervisor's time, formerly spent in replacing absent employees or turnovers, could be put to more productive use. Behavioral-economic measurement provides the methods for highlighting these cost savings.

However, this approach, like human asset accounting, has inherent measurement difficulties. While the return-on-employee-investment is limited to assessing changes in the expected service life of personnel, the behavioral-economic measures include a more complete accounting of financial results. Moreover, while individual and situational differences in skill acquisition and development following a project cannot be accurately assessed using a singular retum-oninvestment measure, a series of benefit measures can reflect that development through behavioral changes. Nevertheless, like asset models, this method incorporates estimations of lost productivity, leaming curve costs, supervisory training time, etc. While the accuracy of these costs can be checked through time-sampled observation, some estimation is always included. Further, some of the dollar components are averaged across persons or incidents of behavior, blurring some of the uniqueness of individual actions. While this methodology can be used for identifying the financial effects of HRD, social benefits can be produced, too. Accounting methods have recently been proposed to estimate the financial gain associated with these social benefits.

Social benefits. The effects of an HRD program can be assessed using traditional psychological and social indicators. For example, improvements in the working environment can be assessed using job observations (Jenkins et al., 1975). Some firms have conducted medical examinations to assess the effects of HRD on employees' health. Most often, however, these social effects are measured using attitude questionnaires. Myers \& Flowers (1974) propose to financially assess employees' attitudes 
by multiplying salary dollar times a weighted attitude score to measure the potential dollar value increases that would be expected from improved attitudes. However, no mention is made of the relationship of these attitudes to the firm's development programs or to resulting behavioral changes. Further, whether the marginal productivity associated with attitude and behavior changes will equal the estimated value improvement is ignored. This work, at best, provides a way for organizations to estimate the impact of organizational salaries on employee morale. It offers little guidance on relating financial improvements to human resource development.

An alternative approach is advanced by Mirvis \& Lawler (in press). Building on the work of Likert $\&$ Bowers (1973), they propose to correlate relevant job attitudes and perceptions with employees' behavior, and using the cost methodology presented earlier, determine the cost-peremployee associated with existing levels of job satisfaction, motivation, etc. When the human resource programs produce attitude changes, future behavioral changes are predicted and a new cost-per-employee level estimated. The degree of estimated behavioral and cost change is predicated on the amount of behavioral variance accounted for in the attitude-behavior relationships. As the projects influence attitudes, behaviors and costs, these estimates are validated against cost reductions.

For example, these authors found the correlation between bank tellers' intrinsic motivation and balancing shortages was -.23 in a midwestern bank employing 160 tellers. The average shortage per teller was $\$ 25.27$ per month. It was estimated that an improvement in intrinsic motivation of .1450 would reduce shortages per teller to $\$ 23.25$ per month. Similar estimates were made incorporating the costs of absenteeism and turnover. Using this approach, gains in intrinsic motivation could be reflected in estimated cost savings.

Following change activities in the bank, it was found that intrinsic motivation increased .1450 and that shortages per teller were reduced to $\$ 21.71$. As such, the actual cost savings only approached the estimate. This model assumes a constant attitude-behavior relationship. Over the course of the project, however, the magnitude of this relationship can change, invalidating the previous estimates. Further, this model assumes a direct relationship. Again, the relationship might be linear or curvilinear. While these factors complicate the calculations, they are easily accommodated into future estimates. This approach provides a means for estimating changes in employee's perceptions and attitudes in financial terms.

Merely reporting social and financial gains does not guarantee that the improvements resulted from the human resource development program. Reduced turnover, for example, may be indicative of employment market conditions, rather than effective employee development. Therefore, it is important for the research team to validate the effectiveness model and underlying theory of HRD. This can be accomplished by observing concommitant improvements in behavioral and attitudinal measures in experimental as opposed to control groups. Further, multivariate analyses should indicate a correlation between the behavioral and attitudinal increases (cf. Azzi, 1973). By validating the effectiveness model, researchers analytically relate financial and social gains to the HRD program. In addition, by estimating the financial impact of employee'attitudes, researchers can provide estimates of future financial improvements. These estimates can serve to justify resource expenditures to otherwise skeptical organizational decision makers. These analyses, however, will account for only a percentage of the variance in resulting benefits. The remaining variance is unrelated to measured variables in the effectiveness model. As this variance becomes large, confidence that HRD produced the benefits is reduced. It remains for the researchers to compare the costs and benefits of an HRD program.

\section{Cost-benefit comparisons}

For illustrative purposes, two diverse examples of HRD cost-benefit comparisons are presented. In the first case, project costs are related with improvements in employee attitudes following an organizational development experiment. In the second case, project costs are contrasted with the financial results of another experiment.

Example 1 . In this case, the costs of an organizational change effort in an engineering design division of a major United States utility company have been computed. Nearly 385 unionized employees, predominantly professional engineers and draftsmen responsible for preparing complex designs and technical drawings, were involved in an 18 month development effort. The 
TABLE 1. Inter-relationships of project's cost and manpower hours in a U.S. Utility

$N=10$

\begin{tabular}{lcccc}
\hline $\begin{array}{l}\text { Consultant's } \\
\text { expense }\end{array}$ & 1.0 & & & \\
$\begin{array}{l}\text { Manpower } \\
\text { Costs }\end{array}$ & $.97^{* *}$ & 1.0 & & \\
$\begin{array}{l}\text { Manpower } \\
\text { hours } \\
\text { Total costs }\end{array}$ & $.99^{* *}$ & $.97^{* *}$ & 1.0 & \\
\hline & $.90^{* *}$ & $.89 * *$ & $.99^{* *}$ & 1.0 \\
\hline & $\begin{array}{l}\text { Consultant's } \\
\text { expense }\end{array}$ & $\begin{array}{l}\text { Manpower } \\
\text { costs }\end{array}$ & $\begin{array}{l}\text { Manpower } \\
\text { costs }\end{array}$ & $\begin{array}{l}\text { Total } \\
\text { costs }\end{array}$ \\
\hline
\end{tabular}

${ }^{* *} p<0.01$

TABLE 2. Relationship of project costs to attitude and attendance changes ${ }^{1}$ in a U.S. Utility $N=10$

\begin{tabular}{lcccc}
\hline $\begin{array}{l}\text { Consultant's } \\
\text { expense }\end{array}$ & -.53 & -.20 & .02 & $.75^{* *}$ \\
$\begin{array}{l}\text { Manpower } \\
\text { costs }\end{array}$ & $-.58^{*}$ & -.22 & .07 & $.72^{* *}$ \\
$\begin{array}{l}\text { Manpower } \\
\text { hours } \\
*\end{array}$ & -.52 & -.19 & .00 & $.77^{* *}$ \\
$\begin{array}{l}\text { Total costs } \\
\text { Intrinsic } \\
\text { motivation }\end{array}$ & Absenteeism & Supervision & $\begin{array}{l}\text { Effort to } \\
\text { performance }\end{array}$ \\
\hline
\end{tabular}

'Reported as 'true' gain score

major costs of the program include the fees and expenses of several consultants, $\$ 124,346$, and the employees' time spent in project meetings, training activities, etc., involving $8,275 \mathrm{hr}$ at a cost of $\$ 95,898$. The total project's costs during this period were $\$ 220,244$.

Table 1 reports the intercorrelations between the consulting expenses, manpower hours, manpower costs, and total costs for ten participating departments. It indicates significant relationships between the two cost components and both are related to the project's departmental manpower hours and, of course, total costs.
$* \mathrm{p}<0.05$

$* * p<0.01$
Table 2 shows the relationship of these cost components and manpower hours with changes in employees' job attitudes and self-reported attendance, measured at the beginning of the project and, again, after 10 months. The changes in attitudes and attendance are reported as "true" gain scores (Cronbach \& Furby, 1970). This measure is calculated by partialling out, through regression, that portion of attitude or attendance change that would be predicted simply from the initial measure, irrespective of the level of development activities. Surprisingly, the table shows that the project's costs are negatively 


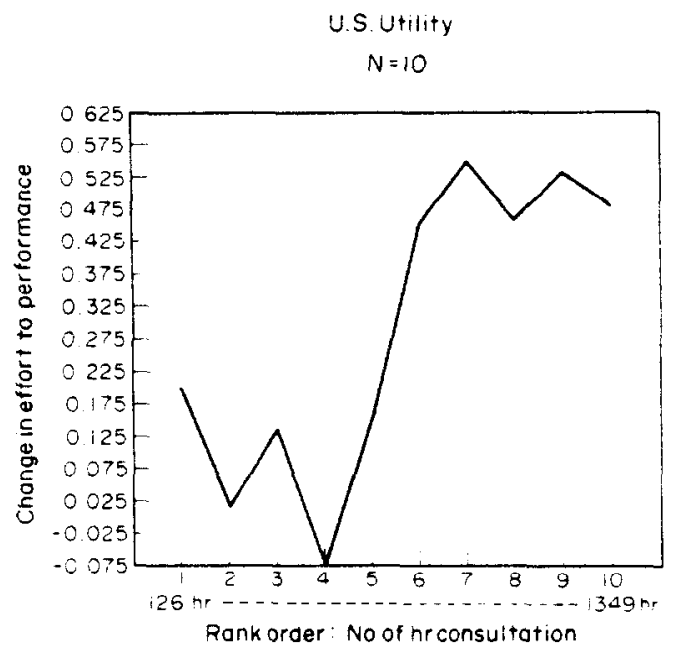

Fig. 2. Total project hours and costs and changes in effort-to-performance beliefs.

related to improvements in intrinsic motivation, that is, in those departments where consultants' and employees' expenses are the highest, employees' personal motivation for doing their jobs well has actually decreased. There is little relationship between the project's costs and improvements in supervision, but some correlation between the costs and reductions in employees' absenteeism. The most significant relationship is between the project's costs and employees' beliefs that effort leads to good performance. Over the course of the project, in those departments where the expenditures are highest, the belief that effort leads to good performance has solidified. Figures 2 and 3 show this effect graphically, depicting the relationship of total project costs and manpower hours with effort-to-performance improvements in each department of the utility.

While Table 2 provides some evidence of the HRD program's effects, it is subject to overinterpretation. First, analyzing the true gain scores with a comparison analysis of variance (Hays, 1973 , p. 596) shows that none of the gain scores used in Table 2 were found to be significant. In essence, after 10 months of an HRD project in the U.S. utility, there was no significant attitudinal change. Second, the number of participating departments is only ten, calling into question the stability of the resulting relationships. Still, in larger organizations with more experimenting units, this problem is minimized and confidence levels can be computed to test the stability of the

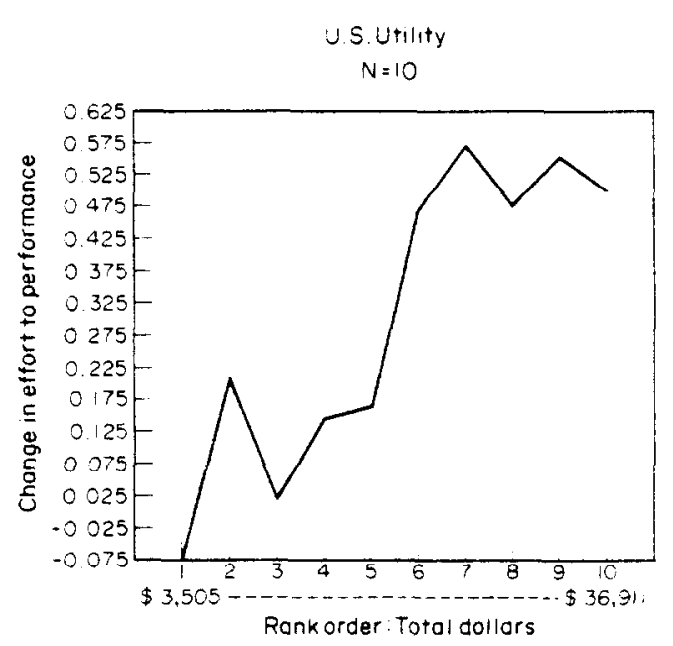

Fig. 3. Total project costs and changes in effort-toperformance beliefs.

resulting correlations. Third, this approach assumes a linear cost-attitude change relationship. This relationship might be curvilinear, but this, too, can be accommodated statistically.

This analysis compares projects with respect to the firm's expenditures, only. It says nothing about the quality of the project. To accomplish this, common qualitative characteristics of the development project can be measured. Questionnaires can ask employees to evaluate the quality of the consultant's work, their understanding of relevant theory, the clarity of their role expectations and the goals of the project, their beliefs about its efficacy, their commitment to the project, etc. .These common descriptors can be related with employees' job perceptions, too. Combining these measures with the firm's expenditures provides a means to relate both the quality and quantity of human resource development activities to employee's perceptions of their work environment. This provides for a comparative assessment of these projects and their impact.

The advantage of this cost and social benefit comparison is that it can be used for ongoing project assessmient. Researchers can gain insight into the early effects of HRD activities, noting areas of attitudinal improvement and the intervening time lags. If warranted, this can stimulate changes in the intensity or direction of HRD activities. Further, it can highlight for organizational decision makers the initial results of the project, albeit, the non-financial ones. The theory 
TABLE 3. Incidents and rates of behaviors at XYZ Corporation 1972-1975

\begin{tabular}{|c|c|c|c|c|c|c|}
\hline \multirow{2}{*}{$\begin{array}{l}\text { Behaviors and } \\
\text { performance }\end{array}$} & \multicolumn{2}{|c|}{$\begin{array}{c}\text { Period 1 } \\
1972-1973\end{array}$} & \multicolumn{2}{|c|}{$\begin{array}{c}\text { Period } 2 \\
1972-1973\end{array}$} & \multicolumn{2}{|c|}{$\begin{array}{l}\text { Period } 3^{*} \\
1972-1973\end{array}$} \\
\hline & $\begin{array}{l}\text { Number of } \\
\text { incidents }\end{array}$ & Rate $(\%)$ & $\begin{array}{l}\text { Number of } \\
\text { incidents }\end{array}$ & Rate $(\%)$ & $\begin{array}{l}\text { Number of } \\
\text { incidents }\end{array}$ & Rate $(\%)$ \\
\hline \multicolumn{7}{|l|}{ Absenteeism ${ }^{\prime}$} \\
\hline Absences & 4,420 & 3.3 & 9.604 & 5.19 & 6905 & 3.76 \\
\hline Leave days & - & - & 12,486 & 6.75 & 13,332 & 7.25 \\
\hline \multicolumn{7}{|l|}{ Accidents } \\
\hline \multicolumn{7}{|l|}{ OSHA } \\
\hline Hourly workforce & 251 & 38.35 & 316 & 35.34 & 208 & 23.76 \\
\hline Salaried workforce & 16 & 17.56 & 12 & 10.90 & 9 & 7.90 \\
\hline Minor $^{2}$ & 3,181 & 421.80 & 6,713 & 706.08 & 5,559 & 635.26 \\
\hline Revisits $^{2}$ & 1.806 & 216.99 & 2,455 & 258.22 & 2,028 & 231.74 \\
\hline \multicolumn{7}{|l|}{ Turnover } \\
\hline \multicolumn{7}{|l|}{ Voluntary } \\
\hline Hourly workforce & 132 & 24.10 & 229 & 29.59 & 116 & 14.57 \\
\hline $\begin{array}{l}\text { Salaried workforce } \\
\text { Involuntary }\end{array}$ & 18 & 17.00 & 29 & 24.17 & 4 & $\begin{array}{l}3.25 \\
\cdot\end{array}$ \\
\hline Hourly workforce & 118 & 21.40 & 161 & 20.80 & 120 & 16.08 \\
\hline Salaried workforce & - & $\longrightarrow$ & 5 & 4.17 & 4 & 3.25 \\
\hline Tardiness ${ }^{3-4}$ & 48 & 8.68 & - & - & - & 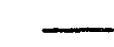 \\
\hline Grievances $^{4}$ & 57 & 10.40 & 40 & 5.17 & 41 & 5.15 \\
\hline
\end{tabular}

*Actual incidents and rates only for 8 month period; projection for the period is reported.

' Hourly workforce; leave days were instituted in periods 2 and 3 are measured and computed as absences.

'Hourly' and salary employees combined.

${ }^{3}$ This is a daily rate: available only in period 1 .

${ }^{4}$ Hourly workforce.

(Source: B. A. Macy \& P. H. Mirvis, $A S Q$, in press)

of HRD argues that these attitudinal improvements will influence financial results. A second example illustrates this cost and financial benefit comparison.

Example 2. In this case, the costs and benefits of HRD at another experimental site are reported. $\mathrm{XYZ}$ Corporation is a unionized manufacturing and supplying plant in a rural area of the United States. It is located in a small community of 8000 people. The plant's average hourly employment for study periods one, two, and three respectively was 652,884 , and 900 persons. The average hourly wage rates per hour during these periods were $\$ 2.67, \$ 2.83$, and $\$ 3.24$ respectively. The average supervisory wage per hour for these same periods were $\$ 6.46, \$ 8.08$, and $\$ 8.50$. The $X Y Z$ workforce was composed of approximately $53 \%$ minority employees; $66 \%$ of the personnel lacked a high school diploma. The firm's cost accounting 
system was a typical industrial product costing system which accumulates cost through direct labor cost centers.

The original social science team was composed of three third-party consultants from the disciplines of social and organizational psychology and productivity measurement. After the initial HRD action period, the social psychologist became the sole project director working with an on-site quality of work committee and an advisory committee. Both of these committees were comprised of union and management personnel from the company and their international union. In addition, the project director had two on-site participant-observers for assistance. The HRD project at $X Y Z$ has been on-going for $3 \mathrm{yr}$. Behavioral and financial data have been collected for 4 yr (i.e. baseline period from May, 1972-April, 1973; period 2 from May, 1973April, 1974; period 3 from May, 1974-April, 1975; and period 4 from May, 1975-April, 1976.

Tables 3 and 4 present the behavioral and financial data for the baseline period and periods 2 and 3 .

Table 3 reflects the incidence and rate of some of the participation membership and performance-on-the-job behaviors over three periods of time at the research site. Such reporting attests to the feasibility of computing measures over multi-year periods, providing the opportunity for change assessment. Table 4 reports the cost per incident and total estimated organizational costs for each behavior measurable at the research site during the baseline and the first two periods of the change activities. Costs for the last period represent data from only eight months, except for production and quality below standard, so for computational purposes, year-end projections were computed and are reported. Constant dollar comparisons indicate a significant cost increase in period 2 and a moderate reduction, approximately $\$ 53,000$ below the baseline figures, in period 3 .

The cost-benefit analyses reported in Table 5 of the HRD project at XYZ Corporation reflect differences from the baseline attendance, tumover, and performance, etc. (see Table 4 for baseline figures). Table 5 indicates total costs have been $\$ 303,588$ during periods 2 and 3 . The total financial gains have been $(-\$ 227,240)$. From a financial viewpoint alone, the $\mathrm{XYZ}$ change experiment had a total net cost-benefit outcome of a $(-\$ 530,828)$.

After two complete years of an HRD project at
XYZ Corporation that entailed over $\$ 300,000$ of external and internal investment, the financial results have been disheartening. However, some social and non-work related benefits are just beginning to appear. Indeed, employees have been exposed to a variety of educational experiences, training opportunities, and health services, all important social aims. Moreover, the experiment is now proceeding into its fourth year with all participation indicating positive changes in labormanagement relations at the site and some experimental groups reporting improvements in individual productivity.

This cost-benefit comparison assumes that all of the financial results are due to the HRD program. A more conservative cost-benefit analysis would compare the project's costs with only that percentage of the variation in financial results which could be traced to measured variables in the effectiveness model. Alternatively, as more comparable HRD experiments are undertaken, it will become possible to attach probabilities to achieving various financial gains. Confidence intervals could be established around the financial benefits and costs could be contrasted with gains weighted by the probability within the interval.

Both examples illustrate comparisons between the costs and benefits of HRD programs. They report only the early findings, but illustrate the use of cost-benefit comparisons in evaluating these undertakings. However, the organization uses distinct criteria in evaluating and interpreting these findings. Specifically, they may attempt to identify either the most cost-effective program or the most cost-beneficial one. Often these are not the same program. This determination can have a decided impact on the future of HRD within a firm.

\section{THE PROBLEM OF EVALUATION}

\section{Cost-effective HRD}

Sometimes the organization will seek to find the most cost-effective human resource development program. These can be of two sorts: (1) the program that maximizes benefits, while keeping expenditures within an accepted range, and (2) the program that reaches an acceptable benefit level, while keeping expenditures to a minimum (both rely on suboptimization with Pareto criteria; 
TABLE 4. Estimated costs of behavior at XYZ Corporation $1972-1975$

\begin{tabular}{|c|c|c|c|c|c|c|c|}
\hline \multirow{2}{*}{$\begin{array}{l}\text { Behaviors and } \\
\text { performance }\end{array}$} & \multicolumn{2}{|c|}{$\begin{array}{c}\text { Period 1 } \\
1972-1973\end{array}$} & \multicolumn{2}{|c|}{$\begin{array}{c}\text { Period } 2 \\
1973-1974\end{array}$} & \multicolumn{3}{|c|}{$\begin{array}{c}\text { Period } 3 \\
1974-1975^{*}\end{array}$} \\
\hline & $\begin{array}{c}\text { Estimated } \\
\text { cost per } \\
\text { incident }(\$)\end{array}$ & $\begin{array}{c}\text { Estimated } \\
\text { total } \\
\text { cost }(\$)\end{array}$ & $\begin{array}{c}\text { Estimated } \\
\text { cost per } \\
\text { incident }(\$)\end{array}$ & $\begin{array}{c}\text { Estimated } \\
\text { total } \\
\text { cost }(\$)\end{array}$ & $\begin{array}{c}\text { Estimated } \\
\text { cost per } \\
\text { incident }(\$)\end{array}$ & & $\begin{array}{c}\text { Estimated } \\
\text { total } \\
\text { cost }(\$)\end{array}$ \\
\hline \multicolumn{8}{|l|}{ Absenteeism ${ }^{1}$} \\
\hline Absences & 55.36 & $\$ 286,360$ & 53.15 & $\$ 510,453$ & 62.49 & $\$$ & 431,494 \\
\hline Leave days & - & - & 55.04 & 687,229 & 61.64 & & 821,795 \\
\hline \multicolumn{8}{|l|}{ Accidents ${ }^{1}$} \\
\hline OSHA & 727.39 & 194,213 & 698.31 & 229,046 & $1,106.52$ & & 240,115 \\
\hline Minor & 6.64 & 21,122 & 5.71 & 38,331 & 6.45 & & 35,856 \\
\hline Revisits & 6.64 & 11,992 & 5.71 & 14,018 & 6.45 & & 13,081 \\
\hline Tardiness ${ }^{1,2}$ & 4.86 & 56,920 & - & - & - & & \\
\hline \multicolumn{8}{|l|}{ Turnover ${ }^{1}$} \\
\hline Voluntary & 120.59 & 18,089 & 131.68 & 33,973 & 150.69 & & 18,083 \\
\hline Involuntary & 120.59 & 14,230 & 131.68 & 21,859 & 150.69 & & 18,686 \\
\hline Grievances & 32.48 & 1,851 & 34.44 & 1,378 & 56.10 & & 2,300 \\
\hline Ouality below standard ${ }^{3}$ & 19.517 & 663.589 & 19,517 & 573,800 & 19.517 & & 409,857 \\
\hline Production below standard ${ }^{4}$ & 22,236 & 266,838 & 22,236 & 335,764 & 22,236 & & 255,714 \\
\hline Total costs 5,6 & & $\$ 1,535,204$ & & $\$ 2,445,851$ & & & $2,246,971$ \\
\hline
\end{tabular}

* Costs associated with absenteeism, leave days, accidents, turnover and grievances during the last 4 months of this period are projections. Product quality and production below standard are actual figures.

${ }^{1}$ Rates and costs for salaried personnel are assumed to be the same as those for hourly employees (Period 1: salaried absence costs - \$41,669; salaried accident costs - $\$ 11,638$; salaried tardiness costs - $\$ 9,641$; salaried turnover costs $\$ 1,829)$.

${ }^{2}$ Average tardiness time was $27 \mathrm{~min}$.

${ }^{3}$ The costs of rejects and scrap was $3.4 \%$ of total sales for period 1 . Each $.1 \%$ reduction is valued at $\$ 19.517$ per incicent. Period 2 costs were $2.94 \%$ of total sales; period 3 costs were $2.1 \%$ of total sales. A constant dollar equivalency of $\$ 19,517$ was used in periods 2 and 3 to discount inflation. Nondiscounted cost of quality below standard in period 2 was $\$ 667,015$ ( $\$ 23,028$ per incident); in period 3 , nondiscounted cost was $\$ 613,970$ ( $\$ 29,237$ per incident).

${ }^{4}$ Plant productivity for period 1 was $88 \%$ of standard. The production below standard rate is $12 \%$, thus, a reduction of $1 \%$ is valued at $\$ 22,236$ per incident. Plant productivity in periods 2 and 3 was $84.9 \%$ and $88.5 \%$ of standard respectively. A constant dollar equivalency of $\$ 22,236$ was used in periods 2 and 3 to discount inflation. Nondiscounted cost of production below standard in period 2 was $\$ 400,567$ ( $\$ 26,528$ per incident); in period 3. nondiscounted cost was $\$ 405.938(\$ 25.299$ per incident).

${ }^{5}$ The total cost in period 1 is $\$ 1,470,427$ for hourly personnel; $\$ 64,777$ for salaried personnel.

- The total cost is reflected in standard labor dollars. The estimated cost in real dollar equivalents in period 1: $\$ 1,688,724$ or $10.4 \%$ of sales; in period $2: \$ 2,690,436$ or $8.45 \%$ of sales; in period $3: \$ 2,471,668$ or $10.61 \%$ of sales. 
TAB LE 5. XYZ Corporation human resource development project cost-benefit analysis

\begin{tabular}{|c|c|c|c|}
\hline & $\begin{array}{l}\text { Period 2 - Initial year HRD } \\
\text { May, 1973-April, 1974 } \\
\text { (Differences from base year) }\end{array}$ & $\begin{array}{l}\text { Period } 3 \text { - Second year HRD } \\
\text { May, 1974-April. } 1975 \\
\text { (Differences from base year) }\end{array}$ & \\
\hline \multicolumn{4}{|l|}{ Costs } \\
\hline $\begin{array}{l}\text { (1) Consultant fees, } \\
\text { expenses, etc.' }\end{array}$ & $\$ 225.000$ & $\$ 61,000$ & \\
\hline $\begin{array}{l}\text { (2) Site employee time, }{ }^{23} \\
\text { training activities, } \\
\text { earned idlc time, etc. }\end{array}$ & 2,403 & 14,585 & \\
\hline Totals & $\$ 227,403$ & $\$ 76,185$ & $\$ 303,588$ \\
\hline \multicolumn{4}{|l|}{ Benefits ${ }^{4}$} \\
\hline $\begin{array}{l}\text { Absenteeism } \\
\text { Leave days }\end{array}$ & $(224,093)$ & $(145,134)$ & \\
\hline $\begin{array}{l}\text { Accidents } \\
\text { OSHA } \\
\text { Minor } \\
\text { Revisits } \\
\text { Tardiness }\end{array}$ & $\begin{array}{r}(34,833) \\
(17,209) \\
(2,026)\end{array}$ & $\begin{array}{r}(45,902) \\
(14,734) \\
(1,089)\end{array}$ & \\
\hline $\begin{array}{l}\text { Tardiness } \\
\text { Turnover }\end{array}$ & 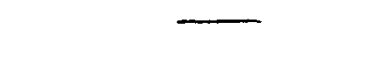 & $\longrightarrow$ & \\
\hline $\begin{array}{l}\text { Voluntary } \\
\text { Non-voluntary }\end{array}$ & $\begin{array}{r}(15,884) \\
(7,629)\end{array}$ & $\begin{array}{c}6 \\
(4,456)\end{array}$ & \\
\hline Grievance & 473 & (449) & \\
\hline Quality below standard & 89,789 & 253,732 & \\
\hline Production under standard & $(68,926)$ & 11,124 & \\
\hline Totals ${ }^{5-7}$ & $(\$ 280,338)$ & $\$ 53,098$ & $(\$ 227,240)$ \\
\hline
\end{tabular}

${ }^{1}$ Nine different organizations and funding agencies contributed action monies to the project. In addition, three organizations provided office space and services to project staff. These action monies do not include any assessment funds.

${ }^{2}$ Prujected for 12 months from 5 months of data during period 2.

${ }^{3}$ Estimates of actual costs are low due to reporting of only hourly personnel.

${ }^{4}$ All estimate of benefits (costs) are indicated in relationship to Table 4.

${ }^{5}$ The HRD project has a negative effect of $\$ 280,338$ in period 2 and a positive effect of $\$ 53,098$ in period 3 compared to the baseline period.

${ }^{\circ}$ Assumes the benefits to be financial only.

${ }^{7}$ Comparing the total costs $(\$ 303,588)$ of the HRD project against the total estimated financial benefits $(-\$ 227,240)$ indicates the project has a net cost -benefit outcome of $(-\$ 530.828)$.

see discussion in Merewitz \& Sosnick, 1971). Utilization of either of these criteria can be a disservice to a HRD program.

In the first case, the organization has determined that the resources to be devoted to HRD are limited. Implicitly, the goals of the HRD program have been ordered against other organizational priorities and the available resources allocated accordingly. However, should market exigencies change, optimization of higher priority objectives may legitimate reductions in the HRD budget. Funds originally designed for employee development are often re-allocated as the market tightens. As a result, only those firms with the strongest philosophical commitment to HRD or those holding substantial uncommitted resources will be able to sustain. a human resource development effort. The financially troubled firm, 
where HRD might have a substantial effect, may decide that a program is too expensive and $\mathrm{drop}$ it from consideration.

In the second case, the organization has determined that resources will be allocated until a pre-determined HRD goal is met. For example, an organization might consider employee challenge to be an important goal. The emphasis they place on challenge is determined by its merit or social good (see discussion by Musgrave, 1959). If merit criteria are used, the organization determines that consumers want goods or services produced by challenged workers, but that consumers are unwilling to pay for this challenge. Hence, the firm or the government is left to subsidize HRD. If social good criteria are employed, the increased cost of employee challenge is passed along to the consumers. In both circumstances, the firm and the market jointly establish an acceptable level of employee challenge. Thus, the most cost-effective program is the one that produces challenge within this accepted range, while minimizing expenditures to the firm. This, too, has consequences for HRD.

Specifically, cost-effectiveness evaluations discourage the full exploration of the potential of HRD. When resources are restricted, the productive possibilities of HRD are ignored. When goals are pre-determined, the potential associated with increased investment is untapped. Accordingly, cost-effectiveness comparisons may actually constrain a human resource development program within a firm. This argues for utilization of cost-beneficial evaluation critiera.

\section{Cost-beneficial $H R D$}

Using cost-benefit criteria, a project would be judged successful if expenditures were outweighed by the present value of future benefits. It would be anticipated that challenged employees, for example, will compensate the firm through increased production and less absenteeism. The most beneficial program is the one that maximizes financial benefits while minimizing expenditures (suboptimization with Kaldor-Hicks criteria; see Merewitz \& Sosnick, 1971). Cost-benefit criteria seem more suited to HRD than cost-effective criteria. They give full reign to the productive capacities of human resource development. They do not constrain investment or goal achievement, rather permit the firm to establish a balance between a project's costs and gains. Yet, it may be unreasonable to expect that the program which maximizes benefits will be the least expensive.
Thus, the organization must identify the optimal investment point. Quirin (1967) argues for optimal determination based on the benefit/cost ratio. Merewitz \& Sosnick (1971) argue that the resulting derivative may cause the firm to cease expenditures short of the point of maximal net benefit. Accordingly, they advocate optimization of the present value of net benefits (benefitscosts). This is the cost-benefit comparison reported in Example 2. Further, this comparison can be modified to incorporate resource limitation constraints where necessary. Nevertheless, costbenefit comparisons should not be the sole criteria for evaluating HRD.

\section{A FINAL NOTE}

Traditional cost-benefits comparisons have relied solely on financial data. They do not incorporate externalities such as the non-financial costs or gains. While accounting methods are being developed to reflect social aims in financial terms, individual growth and well-being, organizational adaptability and goodwill cannot, and perhaps, should not be assigned an economic value. Consequently, decisions made solely to optimize financial gains are unguided by the effects of HRD on non-financial results.

Monsen \& Downs (1968) argue that decision making in the firm is a process of maximizing individual decision maker's utilities. Banner \& Baker (1973) contend that firm's experimenting with HRD are committed to social ends. They note, "Employee satisfaction and growth is a legitimate corporate goal by itself, regardless of whether or not it contributes to profits" (p. 47). Consequently, for decision makers committed to the social goals of HRD, the net benefit point is merely one input into the decision process. Indeed, limiting program evaluation to a single financial indicator counterfeits the underlying philosophy of HRD. The goals of these programs are multifold; evaluation should follow suit. It seems imperative, then, to undertake interdisciplinary assessment of HRD.

The role of interdisciplinary assessment is to inform decision makers in the firm with respect to the full range of effects of HRD. This should not inhibit accountants and other researchers from participating with decision makers in evaluating a project (see discussion by Churchman \& Schainblatt, 1969), rather, it simply argues that all costs 
and benefits be measured and reported. Otherwise, as Hatry (1970) notes, "Key value judgements that are rightfully the task of the political decision making process are instead made by analysts..." (p. 777).

Program evaluation must be guided by measurement, not impressions. Cost and benefit comparisons, under research conditions, provide one test of the merits of HRD. Further, validation of the effectiveness model determines a program's generalizability. The potential of cost-benefit comparisons of HRD are enormous. For example, the data reported here has helped to stimulate the consultants, the management, and the union of the aforementioned XYZ Corporation to reshape their development effort. They are beginning a cost savings program where employees and the management jointly share the financial benefits of increased output and reduced scrap, supply utilization, downtime, and rework. In addition, the management and the union are collaborating in establishing levels of plant efficiency and profitability. This experience suggests that those experimenting with HRD can utilize cost-benefit findings as well as other research information. The researcher's charge is to produce such data. It remains to refine the assessment methods, including the accounting activities, and incorporate them in interdisciplinary assessment in future HRD research.

\section{BIBLIOGRAPHY}

Alexander, M., Investments in People, Canadian Chartered Accountant (July, 1971), pp. 1 -8.

Ash, P., Review of 'Work in America, Personnel Psychology (1973), pp. 597-604.

Azzi, C. F., Equity and Efficiency Effects from Manpower Programs (Lexington, Mass.: Lexington Books, 1973).

Bakke, E. W., The Human Resources Function, Management Intemational Review (1961), pp. 16-24.

Banner, D. \& Baker, G., Human Resource Accounting: A Critical View, MSU Business Topics (Autumn, 1973), pp. 45-52.

Brogden, H. \& Taylor, E., The Dollar Criterion-Applying the Cost Accounting Concept to Criterion Construction, Personnel Psychology (1950), pp. 133-154.

Brummet, R., Flamholtz, E. \& Pyle, W., Human Resource Measurement - A Challenge for Accountants, The Accounting Review (1968), pp. 217-224.

Cheek, L. M., Cost Effectiveness Comes to the Personnel Function, Harvard Business Review (May-June, 1973), pp. 96-105.

Cronbach, L. J. \& Furby, L., How We Should Measure 'Change' - or Should We? Psychological Bulletin (1970), pp. 68-80.

Churchman, C. W. \& Schainblatt, A. H., PPB: How can it be Implemented? Public Administration Review (March-April, 1969), pp. 178-188.

Davis, L. E. \& Cherns, A. B., eds., The Quality of Working Life (New York: The Free Press, 1975).

Dearden, J., The Case against ROI Control, Harvard Business Review (May -June, 1969).

Edwards, E., Guttentag, M. \& Snapper, K., A Decision-Theoretic Approach to Evaluation Research. In E. Struening and M. Guttentag, eds., Handbook of Evaluation Research vol. 1 (Beverly Hills, Cal.: Sage Publications, 1975), pp. 139-182.

Flamholtz, E. G., Assessing the Validity of a Theory of Human Resource Accounting: A Field Study, Joumal of Accounting Research-Empirical Research in Accounting: Selected Studies, 1972.

Flamhoitz, E. G., Human Resource Accounting (Encino, Cal.: Dickenson Publ., 1974).

Hays, W. L., Statistics for the Social Sciences (New York: Holt, Reinhart \& Winston, 1973).

Hatry, H., Measuring the Effectiveness of Nondefense Public Programs, Operational Research Quarterly (October, 1970), pp. 772-784.

Herrick, N., The Quality of Work and its Outcomes: Estimating Potential Increases in Labor Productivity (Columbus, Ohio: The Academy for Contemporary Problems, 1975).

Jenkins, G. D., Nadler, D. A., Lawler, E. E. \& Cammann, C., Standardized Observations: An Approach to Measuring the Nature of Jobs, Joumal of Applied Psychology (1975), pp. 171-181.

Kahn, R. L., Organizational Development: Some Problems and Proposals, Joumal of Applied Behavioral Science (1974), pp. 485-502.

Katzell, R. A., Yankelovich, D., et al., Work, Productivity, and Job Satisfaction (New York: The Psychological Corporation, 1975).

King, B. G., Cost-Effectiveness Analysis: Implications for Accountants, The Journal of Accountancy (March, 1970), pp. 43-49.

Lawler, E. E., Motivation in Work Organizations (Monterey, Calif.: Brooks/Cole Pub. 1973).

Lawler, E. E., Measuring the Human Organization. Paper presented at Human Resource Accounting Seminar, Bonn, Federal Republic of Germany, 1974. 
Lawler, E. E., Evaluation Research: A Needed Emphasis in Organizational Behavior, Paper presented at the Academy of Management Annual Convention, New Orleans, 1975.

Likert, R., New Patterns of Management (New York: MCGraw-Hill, 1961).

Likert, R. \& Bowers, D. G., Improving the Accuracy of $P / L$ Reports by Estimating the Change in Dollar Value of the Human Organization. Michigan Business Review (1973), pp. 15-24.

Macy, B. A. \& Mirvis, P. H., Measuring Quality of Work and Organizational Effectiveness in Behavioral-Economic Terms, Administrative Science Quarterly (in press, 1976).

March, J. \& Simon, H., Organizations (New York: Wiley, 1958).

Merewitz, L. \& Sosnick, S. H., The Budget's New Clothes (Chicago: Marham Publ., 1971).

Mills, T., Human Resources - Why the New Concern? Harvard Business Review (March-April, 1975), pp. 120-134.

Mirvis, P. H. \& Macy, B. A., Human Resource Accounting: A Measurement Perspective, Academy of Management Review (in press, 1976).

Mirvis, P. H. \& Lawler, E. E.. Measuring the Financial Impact of Employee Attitudes, Joumal of Applied Psychology (in press).

Monsen, R. J. \& Downs, A., A Theory of Large Managerial Firms, in P. Lebreton, ed., Comparative Administrative Theory (Seattle: University of Washington Press, 1968), pp. 56-57.

Musgrave, R. A. The Theory of Public Finance (New York, McGraw-Hill, 1959).

Myers, M. S. \& Flowers, V. S., A Framework For Measuring Human Assets, California Management Review (1974), pp. 5-16.

Porter, L. W. \& Steers, R. M. Organization, Work, and Personal Factors in Employee Turnover and Absenteeism, Psychological Bulletin (1973), pp. 151-176.

Pyle, W. C., Monitoring Human Resources - 'On Line', Michigan Business Review (July, 1970), pp. $19-32$.

Quirin, D., The Capital Expenditure Decision (Homewood, Ill.: Irwin, 1967).

Rhode, J. \& Lawler, E. E., Auditing Change: Human Resource Accounting. In M. D. Dunnette, ed., Work and Nonwork in the Year 2001 (Monterey, Calif.: Brooks/Cole Publ., 1973), pp. 154-178.

Rothenberg, 3., Cost-Benefit Analysis: A Methodological Exposition. In M. Guttentag and E. Struening, eds., Handbook of Evaluation Research vol. 2 (Beverly Hills, Cal.: Sage Pub., 1975), pp. 55-88.

Sherwood, C. D., Morris, J. N. \& Sherwood, S., A Multivariate, Nonrandomized Matching Technique for Studying the Impact of Social Interventions. In E. Struening and M. Guttentag, eds., Handbook of Evaluation Research Vol. 1 (Beverly Hills, Cal.: Sage Publ., 1975), pp. 183-226.

Srivastva, S., Salipante, P. F., Jr., Cummings, T. G., Notz, W. W., Bigelow, J. D., Water, J. A., et al., Job Satisfaction and Productivity (Department of Organizational Behavior, Case Western Reserve University, Cleveland, Ohio, 1975).

Steele, S. M. Contemporary Problems to Program Evaluation: Implications for Evaluating Programs for Disadvantaged Adults (Syracuse, New York: Eric Clearinghouse on Education, 1973).

Vroom, V. H., Work and Motivation (New York: Wiley, 1964).

Weiss, R. S. \& Rein, M., The Evaluation of Broad-Aim Programs: Experimental Design, Its Difficulties, and an Alternative, Administrative Science Quarterly (1970), pp. $97-109$.

Woodruff, R., Human Resource Accounting, Canodian Chartered Accountant (1970), pp. 2-7.

Work in America. United States Department of Health, Education, and Welfare: Report of a Special Task Force to the Secretary, Washington, D.C., United States Government Printing Office, 1973. 